\title{
Water Purification capability of a Benthic Ecosystem of varied diversity
}

\author{
KYOKO HATA, ${ }^{1}$ TERUAKI SUZUKI ${ }^{2}$ AND HIROAKI AOYAMA ${ }^{2}$ \\ 1 Institute of Environmental Informatics, METOCEAN ENVIRONMENTAL INC., Yokohama, Kanagawa \\ 224-0025,Jaaapan (can@notes.metocean.co.jp), and ${ }^{2}$ Aichi Fisheries Research Institute, Gamagori, Aichi, 443-0021, Japan
}

SUMMARY: To recover from the decline of a fishing grounds production capacity due to eutrophication in Mikawa Bay, it was examined by a benthic ecosystem model to find out the optimal arrangement of tidal flats, sea grass and seaweed beds, and beach which show maximum purification ability as a whole. In the summer, DIN became a sink $\left(36 \sim 92 \mathrm{mg} \mathrm{N} \mathrm{m} \mathrm{m}^{-2} \mathrm{~d}^{-1}\right)$ for most cases except for both cases of tidal flats occupying whole area $\left(-87 \mathrm{mg} \mathrm{N} \mathrm{m}^{-2} \mathrm{~d}^{-1}\right)$ and sandy beach occupying whole area $\left(-38 \mathrm{mg} \mathrm{N} \mathrm{m}^{-2}\right.$ $\left.\mathrm{d}^{-1}\right)$. PON became a source $\left(-3 \sim-100 \mathrm{mg} \mathrm{N} \mathrm{m}^{-2} \mathrm{~d}^{-1}\right)$ for most cases except for the case of tidal flats occupying whole area ( $33 \mathrm{mg} \mathrm{N} \mathrm{m}^{-2} \mathrm{~d}^{-1}$ ). In these results, TN became a large sink in the case of higher occupation area ratio of sea grass beds, and it became a large source in the case of tidal flats occupying whole area and sandy beach occupying whole area. In the autumn, DIN became a large source $\left(-73 \sim-199 \mathrm{mg} \mathrm{N} \mathrm{m}^{-2} \mathrm{~d}^{-1}\right)$ except for the case of sandy beach occupying whole area $\left(21 \mathrm{mg} \mathrm{N} \mathrm{m}^{-2} \mathrm{~d}^{-1}\right)$. PON became a large sink $\left(70 \sim 307 \mathrm{mg} \mathrm{N} \mathrm{m}^{-2} \mathrm{~d}^{-1}\right)$ except for the case of sandy beach occupying whole area $\left(-41 \mathrm{mg} \mathrm{N} \mathrm{m}^{-2} \mathrm{~d}^{-1}\right)$. In these results, ability to remove for PON became larger with an abundance of macro benthic organisms.

\section{KEY WORDS: ecosystem model, nitrogen cycle, tidal flat, eelgrass bed, purification capability}

\section{INTRODUCTION}

It became clear from research in recent years that tidal flats, sea grass and seaweed beds have a water purification function to play an important role to regulate the coastal water quality, ${ }^{1,2)}$ But, in Japan $38 \%$ and more of the whole tidal flats has disappeared between $1945-1990$ by reclamation, and even at present new reclamation in shallow water regions such as tidal flats, and sea grass and seaweed beds is planned. Aoyama ${ }^{3)}$ presented the changes in the coastline in Mikawa Bay and also the fishing ground environment. Fig. 1 shows changes in transparency, days of red tide occurrences, area ratio of oxygen deficient water masses, inflow load of total Nitrogen (TN) and total phosphorus (TP) in Mikawa bay and a cumulative total reclamation area in east Mikawa. The transparency of Mikawa Bay has been decreasing rapidly from the latter half of 1950's to the latter half of 1960's. Since the decline of the transparency in Mikawa Bay corresponds to the time when the amounts of inflow load increased rapidly, it is supposed to be caused by the expansion of primary production due to increase in the amount of inflow load. On the other hand, the increasing frequency of occurrences of red tides and oxygen deficient water masses are after 1970's, and it corresponds not to the time when the amounts of inflow load increased rapidly, but it corresponds to the time when reclamation of tidal flats increased rapidly. Since the amounts of fishing of short-necked clam in east Mikawa decreased by about 15,000 ton from the 1960 's to 1970 , while the land of about $9.5 \mathrm{~km}^{2}$ was reclaimed, Sasaki ${ }^{4}$ speculated that fishing potential would be $1.6 \mathrm{kgm}^{-2}$ in the lost sea area. As it can be predicted that the reclaimed sea area had a large water purification ability by filter feeder such as short-necked clam, Aoyama) evaluated that the filtration ability of 1785 ha of the reclaimed sea area in east Mikawa is $6.0 \times 10^{7} \mathrm{~m}^{3} \mathrm{day}^{-1}$, taking into account the result of the mactobenthic filtration speed of $140.4 l^{2} \mathrm{~m}^{-2} \mathrm{~h}^{-1}$ (Aoyama and Suzuki ${ }^{5}$ ). This is equivalent to the speed that the seawater of Mikawa Bay (capacity $5.54 \mathrm{~km}^{3}$ ) is filtered in 92 days. It is suggested that one of the factors of environment at aggravation of present Mikawa Bay is the loss of a filtration function by benthic filter feeders.
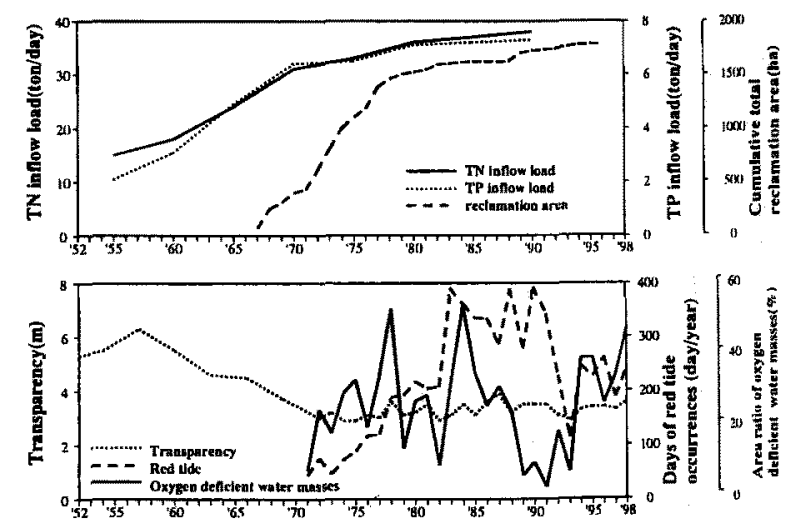

Fig. 1 Changes in transparency, days of red tide occurrences, area ratio of oxygen deficient water masses, inflow load quantity (TN and TP) in Mikawa bay, and a cumulative total reclamation area in east Mikawa. 
It is known those shallow water regions such as tidal flats, sea grass and seaweed beds have a water purification capability ${ }^{2}$ ). Ability to remove of particulate organic matter (POM) from overlying water is large in the sandy tidal flat where bivalves live abundantly, and the ability to remove of dissolved inorganic nutrient from water is large in the sea grass and seaweed beds ${ }^{2,6,7,8,9)}$. But, generally the good fishing grounds of the bivalve and sea grass and seaweed beds don't exist together. In Issiki Tidal Flat, Mikawa Bay, nitrogen biomass of sea grass and seaweed decreased from $1.7 \mathrm{~g} \mathrm{~N} \mathrm{~m}^{-2}$ in 1984 to $0.1 \mathrm{~g} \mathrm{~N} \mathrm{~m}^{-2}$ in 1994 , while the catch of the bivalve in 1994 increased by 1.6 times $^{6}$. From the point of view of water purification capability, the ability to remove TN in 1994 declined about $5 \%$ from that of 1984 while ability to remove particulate organic nitrogen (PON) in 1994 improved about $10 \%$ compared with 1984.

In this study, to recover from the decline of a fishing grounds production capacity due to eutrophication in Mikawa Bay, it was examined by a benthic ecosystem model to find out the optimal arrangement of tidal flats, sea grass and seaweed beds, and beach which show maximum purification ability as a whole.

\section{Study site and Observations}

Mikawa Bay is very shallow bay with $10 \mathrm{~m}$ average depth of water and about $500 \mathrm{~km}^{2}$ surface area. And it is connected with Ise Bay through the channel of the width $9 \mathrm{~km}$, and faces the Pacific Ocean just in the south of this channel through the Irago Channel of the width $12 \mathrm{~km}$. Issiki Tidal Flat is located in the northem part of Mikawa Bay, and it is a front tidal flats about an area of $10 \mathrm{~km}^{2}$ formed by River Yahagi-furukawa. The coastline is about $7 \mathrm{~km}$, and sea bottom is comparatively flat with gentle slope up to about $1.5 \mathrm{~km}$ offshore. Beyond there, the water depth increases to $5 \mathrm{~m}$ abruptly. Fishing is being run actively, mainly consisting of shellfish fishing for the short-necked clam (Ruditapes philippinarum) and the culture of laver (porphyra yezoensis). Ulva pertusa fishing is being done as a peculiar production of this area. Data collection was undertaken at Isshiki Tidal Flat in June 1994. The general water quality, sediment characteristics and biomass of benthic fauna were analyzed.

\section{Model Formulation}

Fig. 2 represents the nitrogen cycle employed in our model. The governing equations for the nitrogen flow in the model were also derived from this concept. The notation of each process in the model follows Baretta and Ruardij ${ }^{10,11)}$.

This model is a "box model", and a pelagic system and has a benthic system touches the sea bottom surface. In both pelagic and benthic systems, the space division in the horizontal direction is being done two-dimensionally. In the vertical direction, one layer for the water column, and two layers of aerobic layer and anaerobic layer for the benthic layer are taken into consideration, and each layer thickness is set up based on the actual measurement values.

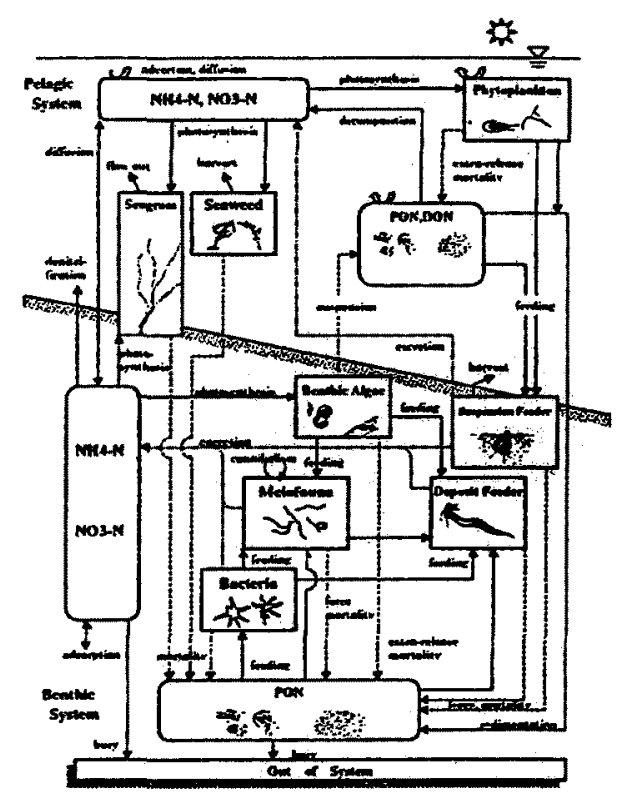

Fig. 2 Model concept. The dashed lines indicate flux from living state variables to detritus.

\section{Conditions of numeric simulation}

The box division of the calculation applied to the sea area of this investigation is shown in Fig.3. The five boxes were made taking the geographical features, depth of water and organism distribution into consideration. And, these box divisions are fitted to the grids of flow calculation of Suzuki ${ }^{\text {G }}$. A number inside each box in Fig. 3 shows a box number. Initial values of calculation were established from the result of field survey carried out in June 1994 (Suzuki ${ }^{6}$ ).

For the flow condition, the simulated results for 1994 (Suzuki ${ }^{6}$ ) was used. The flow rate through sections between the boxes is averaged for one hour. The boundary condition was derived from measurement of water quality and assumed a fixed condition during calculation period. As for the solar radiation and air temperature conditions were used the data of Nagoya local weather station, and for the water temperature condition was used the measurement value. Though the time integration was made for one year from June 1994 to May 1995, total time integration in this 
calculation was made for two years to pay attention to the stability of calculation. A time step was set at thirty minutes.

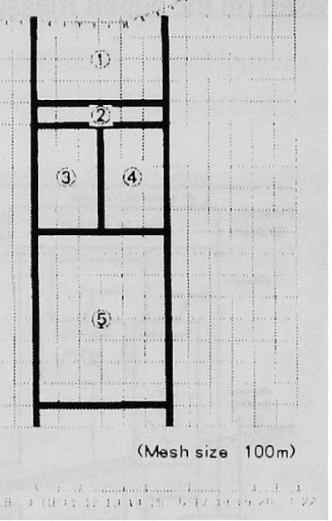

Fig. 3 The box division of the calculation applied to the sea area of this investigation.

\section{MODEL RESULTS}

The nitrogenous circulation in Issiki Tidal Flat in 1994 1995 was computed by using the available result of flow calculation and the benthic ecosystem model (the basic case calculation). Simulated results were compared to the observed results. The model results showed reasonable agreement with observed results. From this result, we estimated the nitrogen flux between water column and sediment. Fig. 4 shows the nitrogen budget for Isshiki Tidal Flat. This figure shows that in spring and summer season organic and inorganic nitrogen became a sink (nitrogen was removed) in this tidal flat, and in autumn season organic nitrogen became a sink and inorganic nitrogen became a source (nitrogen was released to sea water) in this tidal flat. In spring and summer season, dissolved inorganic nitrogen (DIN) is taken up by phytoplankton, benthic algae, sea grass and seaweed. In autumn season, PON is filtered by suspension feeder.

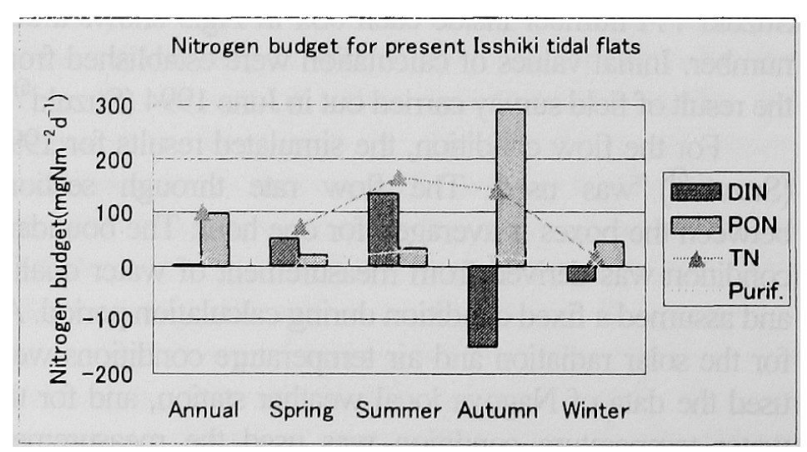

Fig.4 The results of the DIN, PON and TN budget for present Isshiki Tidal Flat.
This result shows that Isshiki Tidal Flats plays important roles for the ambient sea water environment. Removing DIN in spring and summer season suggests the possibility of reducing red tide occurrence, and removing PON in autumn season suggests the possibility of reducing the occurrence of oxygen deficient water masses. In particular, the function of removing POM from seawater in summer and autumn season is the most important function of tidal flats in present Mikawa Bay.

\section{DISCUSSION}

Based on the above basic case, we tried to compute some cases by changing the arrangement of tidal flats, sea grass beds and beach. The arrangement and combination of the tidal flats, sea grass beds and beach in this investigation are shown in Table 1. It is supposed that tidal flats and a beach can not exist at the same time within a fixed area. Therefor, a combination of the tidal flats and the beach is not considered.

Table 1 The case of calculations. In this table, "S.gB." indicate Sea grass Bed.

\begin{tabular}{|c|c|c|c|c|c|}
\hline & BOX1 & BOX2 & BOX3 & BOX4 & BOX5 \\
\hline S(km $)$ & 0.24 & 0.06 & 0.15 & 0.15 & 0.48 \\
\hline \hline Case1 & Tidal Flat & & Tidal Flat & Tidal Flat & Tidal Flat \\
\hline Case2 & S.g. B. & & S.g. B. & S.g. B. & S.g. B. \\
\hline Case3 & Beach & & Beach & Beach & Beach \\
\hline Case4 & Tidal Flat & & Tidal Flat & Tidal Flat & S.g. B. \\
\hline Case5 & Tidal Flat & & Tidal Flat & S.g. B. & S.g. B. \\
\hline Case6 & Tidal Flat & & S.g. B. & S.g. B. & S.g. B. \\
\hline Case7 & Beach & & Beach & Beach & S.g. B. \\
\hline Case8 & Beach & & Beach & S.g. B. & S.g. B. \\
\hline Case9 & Beach & & S.g. B. & S.g. B. & S.g. B. \\
\hline
\end{tabular}

Table 2 Calculation precondition

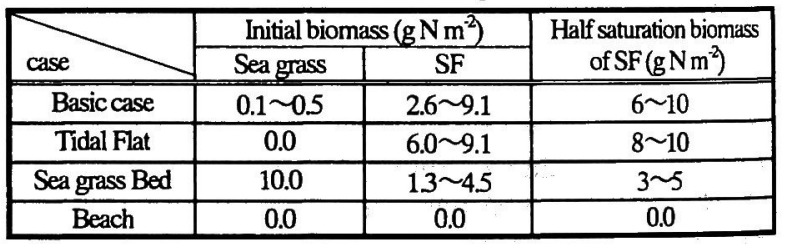

And though both sea grass and seaweed exist in Issiki Tidal Flat, only sea grass bed was considered in this calculation for simplicity. Table 2 shows some assumptions.

Fig. 5 shows the results of the PON, DIN and TN budget for different occupation area ratios of tidal flats, sandy beach and sea grass beds. In the spring case, DIN became a sink $\left(12 \sim 85 \mathrm{mg} \mathrm{N} \mathrm{m}^{-2} \mathrm{~d}^{-1}\right)$ in every arrangement. PON became a source $\left(-2 \sim-60 \mathrm{mg} \mathrm{N} \mathrm{m}^{-2} \mathrm{~d}^{-1}\right)$ except for the case of tidal flats occupying whole area $\left(22 \mathrm{mg} \mathrm{N} \mathrm{m}^{-2} \mathrm{~d}^{-1}\right)$. In these results, TN became a sink. (34 71 $\mathrm{mg} \mathrm{N} \mathrm{m}^{-2} \mathrm{~d}^{-1}$ ) except for the case of sandy beach occupying whole area $(0$ $\mathrm{mg} \mathrm{N} \mathrm{m} \mathrm{m}^{-1}$ ), and maximum purification ability was shown in the case of sea grass beds occupying whole area.. 
In the summer case, DIN became a sink (36 $92 \mathrm{mg}$ $\mathrm{N} \mathrm{m}^{-2} \mathrm{~d}^{-1}$ ) for most cases except for both cases of tidal flats occupying whole area $\left(-87 \mathrm{mg} \mathrm{N} \mathrm{m}^{-2} \mathrm{~d}^{-1}\right)$ and sandy beach occupying whole area. $\left(-38 \mathrm{mg} \mathrm{N} \mathrm{m}^{-2} \mathrm{~d}^{-1}\right)$. PON became a source $\left(-3 \sim-100 \mathrm{mg} \mathrm{N} \mathrm{m}^{-2} \mathrm{~d}^{-1}\right)$ for most cases except for the case of tidal flats occupying whole area $\left(33 \mathrm{mg} \mathrm{N} \mathrm{m}^{-2}\right.$ $\mathrm{d}^{-1}$ ). In these results, TN became a large sink in the case of higher occupation area ratio of sea grass beds, and it became a large source in both cases of tidal flats occupying whole area $\left(-54 \mathrm{mg} \mathrm{N} \mathrm{m}^{-2} \mathrm{~d}^{-1}\right)$ and sandy beach occupying whole area. $\left(-138 \mathrm{mg} \mathrm{N} \mathrm{m}^{-2} \mathrm{~d}^{-1}\right)$.

In the autumn case, DIN became a large source (-73 $\sim-199 \mathrm{mg} \mathrm{N} \mathrm{m}^{-2} \mathrm{~d}^{-1}$ ) except for the case of sandy beach occupying whole area (21mg $\mathrm{N} \mathrm{m}^{-2} \mathrm{~d}^{-1}$ ). PON became a large sink $\left(70 \sim 307 \mathrm{mg} \mathrm{N} \mathrm{m}^{-2} \mathrm{~d}^{-1}\right)$ except for the case of sandy beach occupying whole area $\left(-41 \mathrm{mg} \mathrm{N} \mathrm{m}^{-2} \mathrm{~d}^{-1}\right)$. In these results, ability to remove PON became larger with an abundance of macro benthic organisms.
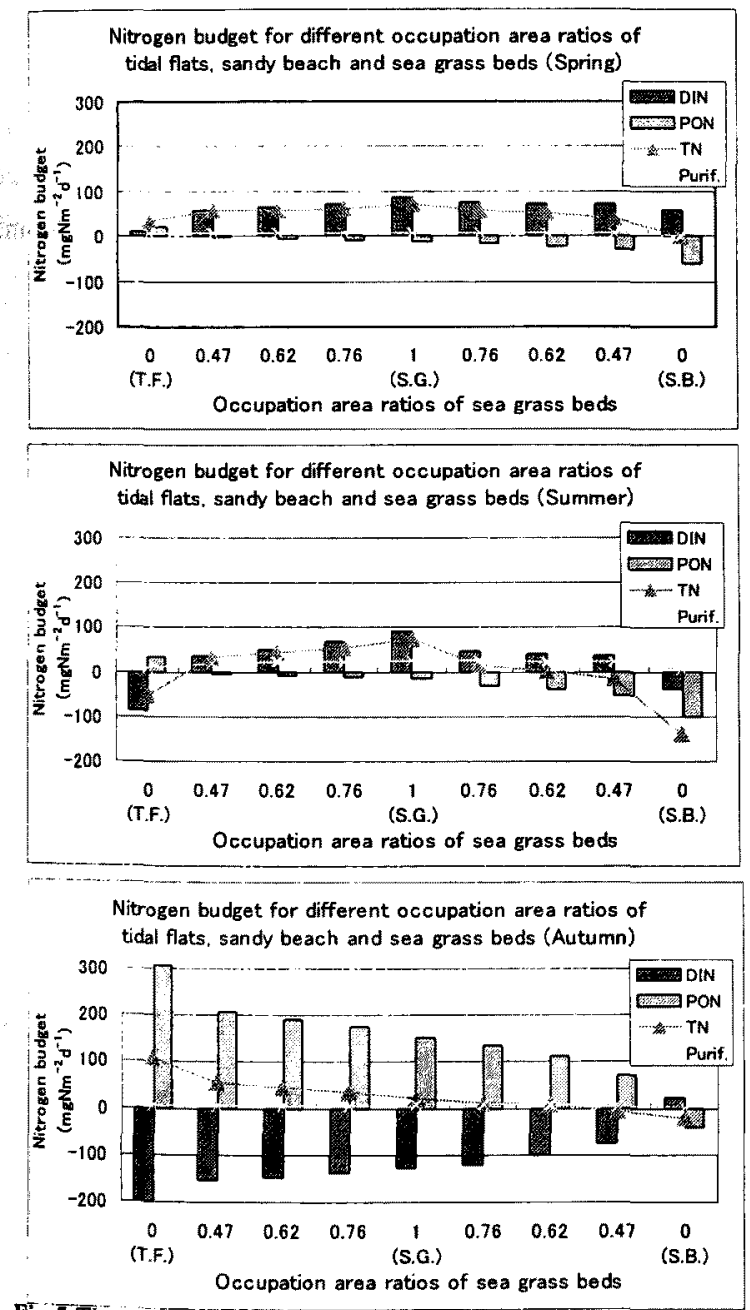

Fig. 5 The results of the DIN, PON and TN budget in spring, summer and autumn for different occupation area ratios of tidal flats, sandy beach and sea grass beds. The left side shows the case of tidal flats occupying whole area $(0 \%$ of the sea grass beds) and the right side shows the case of sandy beach occupying whole area ( $0 \%$ of the sea grass beds). And the middle point of the figure shows the case of sea grass beds occupying whole area.
Comparing the results of arrangement case with that of the basic case, it can be said that the present state of Isshiki Tidal Flat is very good on a point of view of the purification ability.

From this result, it becomes clear that the tidal flats in which benthic organisms are abundant have a high water purification ability but the beach as in which large benthic organisms hardly inhabit don't have it. In particular, it will be able to remove nitrogen from benthic system to outside system, and to maintain sustainable by fishing person, in the case that possible to catch short-necked clam in the tidal flats. Moreover, it is evident that for the improvement of water quality in shallow water, it is necessary to develop a construction technology, not a mere injection of sand in shallow water but the development of tidal flats where large quantities of benthic organisms are nourished.

\section{REFERENCES}

1. Kurihara Y. The Estuarine Ecology and The Eco-technology. Tokai Univ. Press. 1988; Pp.335. (In Japanese)

2. Nakata K, Hata K. Evaluation of Nutrient Cycle in Tidal Flat. J. Japan Society on Water Environment 1994; Vol.17, No.3: 158-166. (In Japanese)

3. Aoyama $\mathrm{H}$. Changes to the Mikawa Bay coastline and fishing ground environments. Bulletin of the Aichi Fisheries Research Institute 2000; No.7 (In Japanese)

4. Sasaki K. Material Circulation and Production in Estuary and Tidal Flat (27) AQUABIOLOGY 1998; 117, 305-309.

5. Aoyama H, Suzuki T. In Situ Measurement of Particulate Organic Matter Removal rates by a Tidal Flat Macrobenthic Community. Bulletin of the Japanese Society of Fisheries Oceanography 1997; Vol. 61, No. 3: 265-274 (In Japanese)

6. Suzuki $\mathrm{T}$, Aoyama $\mathrm{H}$, Hata $\mathrm{K}$. The quantification of Nitrogen cycle on tidal flat by ecosystem model. -In the case of Isshiki tidal flat in Mikawa bay-. J. Advanced Marine Science and Technology Society 1997; Vol.3, No.1: 63-80.(In Japanese)

7. Hata K, Oshima I, Nakata K. Evaluation of the Nitrogen Cycle in a Tidal Flat. Estuarine AND Coastal Modeling, American Soc. of Cïvil Eng 1995; 542-554.

8. Hata K, Oshima I, Nakata K. Evaluation of near-shore benthic nitrogen cycle using benthic ecosystem model. $J$. Advanced Marine Science and Technology Society 1997; Vol.3, No.1: 31-50.(In Japanese)

9. Hata K, Nakata K. Evaluation of eelgrass bed nitrogen cycle using an ecosystem model. Environmental Modelling \& Software 1998; 13: 491-502.

10. Baretta JW, and Ruardij P. Tidal Flat Estuaries. Simulation and Analysis of the Ems Estuary. Ecological Studies 71. Springer-Verlag, 1988, 353pp.

11. Baretta JW, Baretta-Bekker JG, Ruardij P. From Ems to ERSEM, toward generic coastal ecosystem models. AQUABIOLOGY 1996; Vol.18, No.3, 197-209.(In Japanese) 